\title{
Use of red mud activated at different temperatures as a low cost adsorbent of reactive dye
}

\author{
Uso de lama vermelha ativada em diferentes temperaturas como um \\ adsorvente de baixo custo de corante reativo

\begin{abstract}
Maria Lucia Pereira Antunes ${ }^{\circledR}$, Fabiano Tomazini Conceição ${ }^{2 *}{ }^{\oplus}$, Guillermo Rafael Beltran Navarro ${ }^{\circledR} \odot$, Alexandre Martins Fernandes ${ }^{2} \odot$, Steven Frederick Durrant ${ }^{1}$
\end{abstract}

口-

\begin{abstract}
Red mud, a waste product generated during alumina extraction from bauxite, could be used as a low-cost adsorbent. Here, the effect of thermal treatment on the adsorption of Reactive Blue 19 (RB19) dye by red mud was compared with the adsorption capacity of untreated red mud. Thermal treatment of red mud at $500^{\circ} \mathrm{C}$ results in an increase in adsorption capacity from $357 \mathrm{mg} \mathrm{g}^{-1}$ (untreated red mud) to $416 \mathrm{mg} \mathrm{g}^{-1}$, under acidic conditions. Red mud samples thermally treated at $600^{\circ} \mathrm{C}$ and $800^{\circ} \mathrm{C}$ show a reduction in adsorption capacity, however, falling to $337 \mathrm{mg} \mathrm{g}^{-1}$, in acid medium. The change in the maximum adsorption capacity of red mud to RB19 following thermal treatment is associated with specific surface area. Red mud subjected to $500^{\circ} \mathrm{C}$ can be used for the treatment of water and wastewaters with a higher efficiency than untreated red mud, thus finding possible application in the textile industry.
\end{abstract}

Keywords: low-cost adsorbent; isotherms models; environmental management; cleaner production.

\section{RESUMO}

O resíduo de refino de bauxita (lama vermelha) é um resíduo importante gerado na produção de alumínio, podendo ser utilizado como adsorvente de baixo custo. Este estudo teve como objetivo investigar a influência do tratamento térmico na adsorção do corante azul reativo (RB19) por lama vermelha, comparando com a capacidade de adsorção de lama vermelha não tratada termicamente. O tratamento térmico da lama vermelha até $500^{\circ} \mathrm{C}$ resultou em aumento da capacidade de adsorção variando seu valor de $357 \mathrm{mg} \mathrm{g'} \mathrm{(lama} \mathrm{vermelha} \mathrm{não} \mathrm{tratada)} \mathrm{a} 416$ mg g', em condições ácidas. No entanto, amostras de lama vermelha tratadas termicamente a 600 e $800^{\circ} \mathrm{C}$ mostraram uma redução na capacidade de adsorção, chegando a 337 mg g' em meio ácido. A mudança na capacidade máxima de adsorção de RB 19 na lama vermelha tratada termicamente está associada a valores de área superficial específica. Assim, é possível concluir que a lama vermelha tratada termicamente em $500^{\circ} \mathrm{C}$ pode ser utilizada para o tratamento de água e águas residuárias com maior eficiência do que a lama vermelha natural nas indústrias têxteis, contribuindo para novos insights sobre possíveis aplicações na indústria têxtil.

Palavras-chave: adsorvente de baixo custo; modelos de isotermas; gestão ambiental; produção mais limpa.

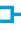

\section{INTRODUCTION}

Brazilian mining activities contribute significantly to global mineral production, including the largest global production of niobium, the second largest production of iron and manganese, and the third largest production of bauxite (BRASIL, 2018). Mineral production, however, carries with it the generation of a huge amount of residue. In 2017, Brazil benefited more than 35 megatons of bauxite via the Bayer Process, which involves the digestion of crushed bauxite in concentrated caustic soda $(\mathrm{NaOH})$ under elevated temperatures and pressure, generating a residue denominated red mud. According to Fortes et al. (2016), about 10 to 25 million tons/year of red mud are generated in Brazil. Red mud is generally characterized

as a complex slurry ( $45 \%$ liquor and $55 \%$ solid) of mixed oxides and trace metals in a highly alkaline matrix. The disposal of red mud usually occurs in tailing dams, producing high financial and environmental costs (JONES; HAYNES, 2011; POWER; GRÄFE; KLAUBER, 2011; GOMES et al., 2016).

The textile industry is of great importance in the economies of several countries, generating a large volume of industrial effluents with high concentrations of dyes and chemical products, which can cause serious environmental problems. In particular, it should be noted that reactive dyes, due to their advantages of having bright and stable colors and being easy to apply, have been identified as the dyes most commonly consumed by the textile industry worldwide (PAPIC et al.,

\footnotetext{
"Universidade Estadual Paulista "Júlio de Mesquita Filho" - Sorocaba (SP), Brazil. ¿Universidade Estadual Paulista "Júlio de Mesquita Filho" - Rio Claro (SP), Brazil. *Corresponding author: ftomazini@rc.unesp.br

Conflicts of interest: the authors declare no conflicts of interest.

Funding: none.

Received: 10/31/2018 - Accepted: 09/10/2O2O - Reg. ABES: 20180180
} 
2004). The processing techniques applied to these effluents are combined biological treatment with physical or chemical processes, which have high efficiency in the removal of organic matter (FIGUEIREDO et al., 2011). However, color removal from effluents is a major problem. Many dyes are stable to light, heat, and oxidizing agents, and are resistant to conventional treatments (OLIVEIRA et al., 2016).

The removal of reactive dyes by a single treatment process is difficult due to their molecular arrangement and excellent solubility in water. The best solution for color removal is a combination of conventional treatments, followed by additional processes, such as chemical oxidation (MOHAN; BALASUBRAMANIAN; SUBRAMANIAN, 2001; LING; WANG; PENG, 2010), membrane filtration (SOJKA-LEDAKOWICZ et al., 2010), different low-cost adsorbents for dye removal (GUPTA; SUHAS, 2009) and coagulation (STEPHENSON; DUFF, 1996). Adsorption shows the best results and is more frequently applied in industry (CRINI, 2006). Most commercial systems for the removal of dyes from industrial wastewater use activated carbon as adsorbents. Good results have been obtained with different alternative materials and at low cost (GUPTA; SUHAS, 2009).

Red mud is used as a low-cost adsorbent in environmental remediation and industrial effluent treatment. The first report of red mud used as a dye adsorbent was by Namasivayam and Arasi (1997). After that, many studies have used red mud as an adsorbent of different dyes (NAMASIVAYAM; YAMUNA; ARASI, 2001, 2002; GUPTA; SUHAS; SAINI, 2004; WANG et al., 2005; TOR; CENGELOGLU, 2006; SILVA FILHO et al., 2008; WANG et al., 2009; NOROUZI; BADII; ARDEJANI, 2010; BHATNAGAR et al., 2011; RATNAMALA; SHETTY; SRINIKETHAN, 2012; SOUZA et al., 2013; SOUZA; ANTUNES; CONCEIÇÃO, 2013; SHIRZAD-SIBONI et al., 2014; JESUS et al., 2015; SAHU; SAHU; PATEL, 2015; OLIVEIRA et al., 2016; BACIOIU et al., 2017). To our best knowledge, however, there are no extant reports on the effects of thermal treatment on bauxite refinery residue as a reactive dye adsorbent.

In this study, the effects of thermal treatment at different temperatures, i.e., $400,500,600$, and $800^{\circ} \mathrm{C}$, of bauxite residue on the adsorption capacity of an anionic reactive dye used in the textile industry, reactive blue 19 (RB19) (Figure 1), was compared to the adsorption capacity of untreated red mud. Untreated and thermally treated red muds used in this work were characterized by $\mathrm{pH}$, electrical conductivity, major oxide composition, mineralogy, and specific surface area. The influence of $\mathrm{pH}$ on the adsorption tests in untreated and thermally treated red mud was also evaluated. Adsorption isotherms were studied using Langmuir and Freundlich models to better understand the reactive dye adsorption characteristics of these low-cost adsorbents. The results

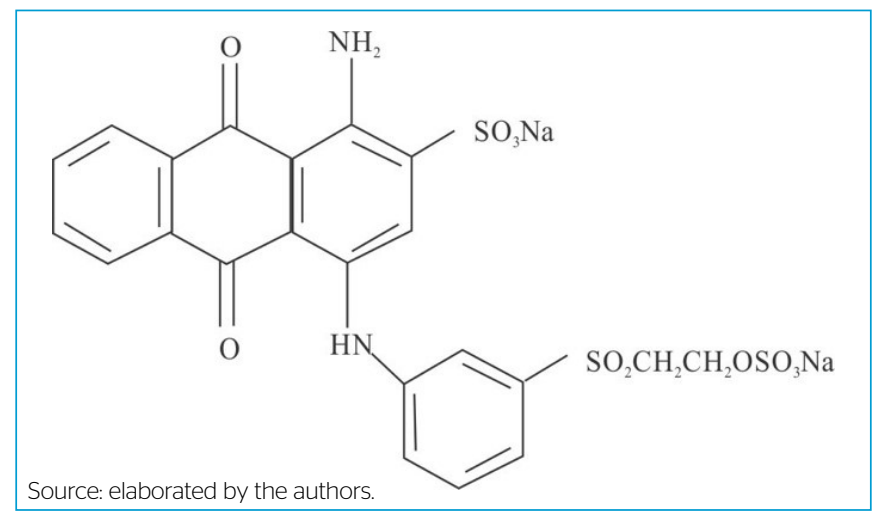

Figure 1 - Molecular Structure of RB19 $\left(\mathrm{C}_{22} \mathrm{H}_{16} \mathrm{~N}_{2} \mathrm{O}_{11} \mathrm{~S}_{3} \mathrm{Na}_{2}\right)$. provide new insight into the relative importance of the use of low-cost adsorbents on cleaner production, especially the reduction of the toxic substances generated by the textile industry.

\section{METHOD}

\section{Sampling, activation, and characterization}

Samples of Brazilian red mud were provided from the alumina plant located at Alumínio City, São Paulo State (Brazil). Initially, all samples were dried at $40^{\circ} \mathrm{C}$ overnight $(\mathrm{RM})$. The samples were heated in a furnace for 3 hours at $400^{\circ} \mathrm{C}$ (RM400), $500^{\circ} \mathrm{C}(\mathrm{RM} 500), 600^{\circ} \mathrm{C}(\mathrm{RM} 600)$, and $800^{\circ} \mathrm{C}$ (RM800).

The $\mathrm{pH}$ and electrical conductivity (EC) values for RM, RM400, RM500, RM600, and RM800 were determined using the ratio 1:25 ( $\mathrm{g}$ of red mud per $\mathrm{mL}$ of distilled and deionized water). The system was stirred continuously for $10 \mathrm{~min}$ utes at $250 \mathrm{rpm}$ and, then, remained at rest for 60 minutes. After this, the $\mathrm{pH}$ and the electrical conductivity in the supernatant liquid were measured using a direct reading equipment by YSI, model YSI 556 . High purity standards were used for calibration of pH $4.00\left(4.00 \pm 0.01\right.$ at $\left.25 \pm 0.2^{\circ} \mathrm{C}\right)$ and $7.00(7.00 \pm 0.01$ at $25 \pm$ $0.2^{\circ} \mathrm{C}$ ). The electrical conductivity meter was calibrated using a standard solution of $\mathrm{KCl}\left(1.0 \mathrm{mmol} \mathrm{L}^{-1}\right)$ of known conductivity, namely $147 \mu \mathrm{Sm}^{-1}$ at $25^{\circ} \mathrm{C}$.

$\mathrm{X}$-Ray diffraction (XRD) was used to determine mineral composition using a Philip X-Pert wide angle X-ray diffractometer, operating at $40 \mathrm{kV}$ and $40 \mathrm{~mA}$, with $\mathrm{CuK} \alpha$ radiation. The morphologies of untreated and thermallytreated red mud samples were observed using a JEOL JSM-6010LA Scanning Electron Microscope with an Energy Dispersive X-ray Spectrometer (SEMEDS). For each sample, the specific surface area (SSA) was measured by BET/ $\mathrm{N}_{2}$ adsorption, using a Micromeritics ASAP 2010 instrument.

\section{Adsorption studies}

Adsorption experiments were undertaken in triplicate using RM, RM400, RM500, RM600, and RM800 and the Reactive Blue 19 (RB19) dye as adsorbate, whose characteristics are shown in Souza et al. (2013). Maximum absorbance at $590 \mathrm{~nm}$ was observed for the aqueous solution, regardless of the $\mathrm{pH}$. Adsorption equilibrium of the RB19 was reached within one hour. The influences of the $\mathrm{pH}$ on the experiments were studied using two different values: (a) natural $\mathrm{pH}$ of Brazilian red mud (10.0); and (b) in the best $\mathrm{pH}$ condition for adsorption of RB19 by red mud (4.0), as described by Souza, Antunes e Conceição (2013).

Isothermal studies were carried out using $0.20 \mathrm{~g}( \pm 0.01 \mathrm{~g})$ of different samples of red mud and $50 \mathrm{~mL}$ of RB19 solution in concentrations of 100 to $5,000 \mathrm{mg} \mathrm{L}^{-1}$, at $\mathrm{pH} 4$ and 10 . The system was maintained under continuous stirring at $250 \mathrm{rpm}$, for 1 hour and a temperature of $25^{\circ} \mathrm{C}$. An aliquot was subsequently collected from the supernatant, which was centrifuged at 3,500 rpm for 5 minutes, and the RB19 concentration was determined.

RB19 concentrations were determined by using a Hach DR-2800 spectrophotometer, measuring at a wavelength of $590 \mathrm{~nm}$. Deionized water was used as a blank sample. The amount of RB19 adsorbed onto the different samples of red mud, $q_{\mathrm{e}}\left(\mathrm{mg} \mathrm{g}^{-1}\right)$ was calculated using the mass balance relationship presented in Equation 1. The percent adsorption (\%A) of RB19 was calculated using Equation 2.

$q_{e}=\frac{\left(C_{o}-C_{e}\right) \cdot V}{W}$ 
$\% A=\frac{\left(C_{o}-C_{e}\right)}{C_{o}} .100$

Where:

$C_{0}$ and $C_{\mathrm{e}}=$ initial and equilibrium concentration of dye, respectively $\left(\mathrm{mg} \mathrm{L}^{-1}\right)$;

$V=$ volume of solution $(\mathrm{L})$;

$W$ = weight of adsorbent sample $(\mathrm{g})$.

\section{Adsorption isotherms}

Analysis of the adsorption isotherms was achieved by adjusting the Langmuir and Freundlich adsorption models. An assumption of the Langmuir Model (Equation 3) is that maximum adsorption corresponds to a saturated monolayer of adsorbate molecules on the adsorbent surface at a constant energy. The Freundlich Model is an empirical isotherm that can be used for non-ideal sorption involving heterogeneous surface energy systems (Equation 4).

$q_{e}=\frac{\left(q_{m} \cdot K_{L} \cdot C_{e}\right)}{\left(1+K_{L} \cdot C_{e}\right)}$

$q_{e}=K_{F} \cdot C_{e^{\frac{1}{n}}}$

Where:

$K_{\mathrm{L}}=$ Langmuir constant related to the energy of adsorption $\left(\mathrm{mg}^{-1}\right)$;

$q_{\mathrm{m}}=$ maximum amount of adsorption corresponding to complete monolayer coverage of the surface $\left(\mathrm{mg} \mathrm{g}^{-1}\right)$;

$K_{\mathrm{F}}=$ Freundlich constant;

$n=$ constant $(1 / \mathrm{n}$ is the adsorption intensity).

\section{RESULTS AND DISCUSSION}

\section{Characterization and influence of $\mathrm{pH}$ on adsorption experiments}

Table 1 presents the characteristics of RM, RM400, RM500, RM600, and RM800. The pH ranges between 9.9 (RM600) and 10.8 (RM500), confirming the high alkalinity of this material, which is caused by the addition of $\mathrm{NaOH}$ during the Bayer process, and is retained even after heat treatment. The values of EC were almost constant, ranging from 3,700 to $3,600 \mu \mathrm{S} \mathrm{cm}^{-1}$. Furthermore, thermal activation causes an increase in SSA for RM400 $\left(43.5 \mathrm{~m}^{2} \mathrm{~g}^{-1}\right)$, RM500 $\left(44.3 \mathrm{~m}^{2} \mathrm{~g}^{-1}\right)$, and RM600 $\left(30.2 \mathrm{~m}^{2} \mathrm{~g}^{-1}\right)$ in relation to RM $\left(18.7 \mathrm{~m}^{2} \mathrm{~g}^{-1}\right)$. However, the SSA value for RM800 $\left(15.9 \mathrm{~m}^{2} \mathrm{~g}^{-1}\right)$ is lower than that of RM.

The morphology of RM, RM400, RM500, RM600, and RM800 particles was observed by scanning electron micrographs, with Figure 2 illustrating the morphology of RM and RM500. Particles of different sizes and shapes were observed. Heterogeneous materials with particle diameters ranging from lower than $1 \mu \mathrm{m}$ to greater than $10 \mu \mathrm{m}$ are seen. In addition, the thermal treatment did not change the mineral morphology. Using the SEM-EDS, it is possible to discern that the smallest particles correspond to iron oxides and the largest ones to silicon.

The mineralogical characterizations of RM, RM400, RM500, RM600, and $\mathrm{RM} 800$ are shown in Table 2. The $\mathrm{RM}$ presents calcite $\left(\mathrm{CaCO}_{3}\right)$, goethite $(\mathrm{FeO}(\mathrm{OH}))$, hematite $\left(\mathrm{Fe}_{2} \mathrm{O}_{3}\right)$, quartz $\left(\mathrm{SiO}_{2}\right)$, gibbsite $\left(\mathrm{Al}(\mathrm{OH})_{3}\right)$, rutile $\left(\mathrm{TiO}_{2}\right)$, and sodalite $\left(\mathrm{Na}_{8} \mathrm{Al}_{6} \mathrm{Si}_{6} \mathrm{O}_{24} \mathrm{Cl}_{2}\right)$. Following thermal treatment, however, peaks caused by aluminum and iron hydroxides disappear from the RM400, RM500, and RM600 XRD patterns. According to Antunes et al. (2012), thermal treatment is responsible for changing goethite to hematite at $306^{\circ} \mathrm{C}(\mathrm{FeO}(\mathrm{OH}) \rightarrow$ $\left.\mathrm{Fe}_{2} \mathrm{O}_{3}\right)$ and the gibbsite is transformed to transition aluminas $\left(\chi \mathrm{Al}_{2} \mathrm{O}_{3}\right)$ at $276^{\circ} \mathrm{C}$,

Table 1 - Characterization of RM, RM400, RM500, RM600, and RM800.

\begin{tabular}{l|c|c|c} 
Sample & $\mathrm{pH}$ & $\mathrm{EC}\left(\boldsymbol{\mu} \mathbf{S ~ \mathrm { cm } ^ { - 1 } )}\right.$ & $\mathrm{SSA}\left(\mathrm{m}^{2} \mathbf{g}^{-1}\right)$ \\
\hline RM & 10.5 & 3,700 & 18.7 \\
\hline RM400 & 10.3 & 3,650 & 43.5 \\
\hline RM500 & 10.8 & 3,600 & 44.3 \\
\hline RM600 & 9.9 & 3,600 & 30.2 \\
\hline RM800 & 10.4 & 3,600 & 15.9 \\
\hline
\end{tabular}

Source: elaborated by the authors.

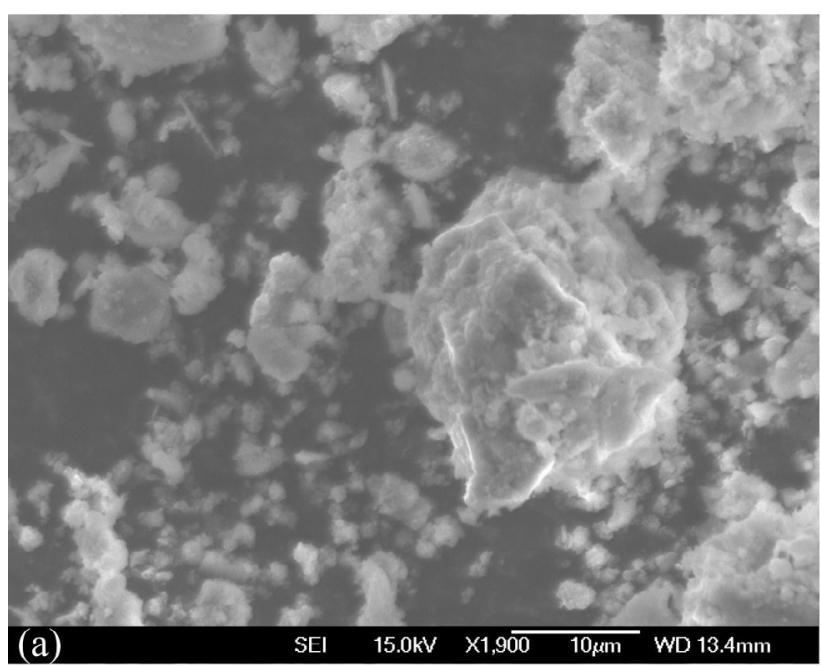

Source: elaborated by the authors

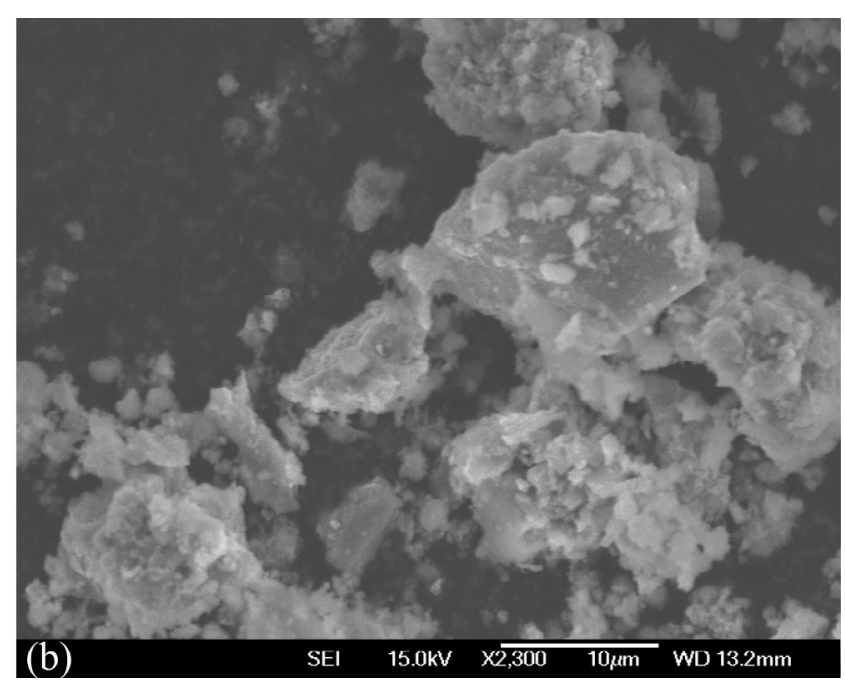

Figure 2 - SEM-EDS of (A) RM and (B) RM500. 
i.e. $\mathrm{Al}(\mathrm{OH})_{3} \rightarrow \mathrm{Al}(\mathrm{OH})_{(\mathrm{S})}+\mathrm{H}_{2} \mathrm{O} \rightarrow \mathrm{Al}_{2} \mathrm{O}_{3}+\mathrm{H}_{2} \mathrm{O}$. This fact explains the increase in specific surface area in the RM400 and RM500, since the transition aluminas have a higher specific surface area than the original hydroxide (WEFERS; MISRA, 1987). At $800^{\circ} \mathrm{C}$, the mineral phase was the same found for RM400, RM500, and RM600, with the exception of calcite, which was decomposed at $681^{\circ} \mathrm{C}\left(\mathrm{CaCO}_{3} \rightarrow \mathrm{CaO}_{(\mathrm{S})}+\mathrm{CO}_{2}\right)$, according to Mercury et al. (2011). In addition, at $800^{\circ} \mathrm{C}$ the amorphous content decreases and two crystalline phases $\left(\mathrm{Ca}_{2} \mathrm{Al}_{2} \mathrm{SiO}_{7}\right.$ - gehlenite and $\left.\mathrm{Ca}_{2} \mathrm{SiO}_{4}\right)$ may be formed by thermal reaction between kaolinite and calcite (LIAO; ZENG; SHIH, 2015). Finally, sodalite is unaffected by the thermal treatment used in this study, since it decomposes only at $1,198^{\circ} \mathrm{C}$ (MERCURY et al., 2011).

Figure 3 shows the removal of RB19 by RM, RM400, RM500, RM600, and $\mathrm{RM} 800$ at $\mathrm{pH} 4.0$ and 10.0. The analysis of RB19 removal demonstrated small differences under each condition. The relative standard deviation for all samples was lower than $4 \%$. For the acidic condition ( $\mathrm{pH} 4.0$ ), the maximum percent

Table 2 - Mineral phase identified in the RM, RM400, RM500, RM600, and RM800.

\begin{tabular}{l|c|c|c|c|c} 
Mineral phase & RM & RM400 & RM500 & RM600 & RM800 \\
\hline Hematite & ++ & ++ & ++ & ++ & ++ \\
\hline Goethite & ++ & - & - & - & - \\
\hline Quartz & + & + & + & + & + \\
\hline Gibbsite & ++ & - & - & - & - \\
\hline Calcite & + & + & + & + & - \\
\hline Sodalite & ++ & ++ & ++ & ++ & ++ \\
\hline Rutile & + & + & + & + & + \\
\hline Magnetite & - & - & - & - & + \\
\hline
\end{tabular}

++: abundant; +: detected; ;: absent. Source: elaborated by the authors. adsorption (\%A) of RB19 was $96 \%$ for lower concentrations (500 $\mathrm{mg} \mathrm{L}^{-1}$ ), decreasing to $8 \%$ in high RB19 concentration $\left(5,000 \mathrm{mg} \mathrm{L}^{-1}\right)$. For all concentrations tested at $\mathrm{pH} 10.0$, the percentage removal of RB19 was between 4 and $27 \%$. This $\mathrm{pH}$ value is near the point of zero charge, with a value of around 9.0 for untreated red mud collected in the same aluminium plant located at Alumínio City and previously described by Antunes et al. (2012), indicating that the surface charge of red mud is neutral and, therefore, suggesting a lower adsorption capacity.

\section{Adsorption isotherms}

The equilibrium relationship between the concentration of an adsorbate in the solid phase and its concentration in the liquid phase at constant temperature and pressure is described by isotherms. Figure 4 shows the adsorption of RB19 dye onto RM, RM400, RM500, RM600, and RM800, at pH 4 (a) and $\mathrm{pH} 10.0$ (b). The parameters of Freundlich and Langmuir isotherms are shown in Table 3. The relative standard deviation for all samples was lower than $4 \%$.

RB19 adsorption in untreated and thermally treated red mud was higher when the concentration of RB19 in the contact solution was lower. The highest values of $\mathrm{R}^{2}$ were obtained with the Freundlich model for untreated or thermally treated red mud, regardless of $\mathrm{pH}$. Thus, for this application, the Freundlich model represents heterogeneous adsorption of RB19 in untreated or thermally treated red mud.

At $\mathrm{pH}$ 10, the maximum adsorption capacities were lower than those measured at $\mathrm{pH} 4$, as explained above. At $\mathrm{pH} 4.0$, the maximum adsorption capacity $\left(q_{\mathrm{m}}\right)$ was observed at $400^{\circ} \mathrm{C}\left(403 \mathrm{mg} \mathrm{g}^{-1}\right)$ and $500^{\circ} \mathrm{C}\left(416 \mathrm{mg} \mathrm{g}^{-1}\right)$ in relation to $\mathrm{RM}\left(357 \mathrm{mg} \mathrm{g}^{-1}\right)$. For sample RM600, the $q_{\mathrm{m}}$ value $\left(370 \mathrm{mg} \mathrm{g}^{-1}\right)$ was lower than the values found for RM400 and RM500. Condition RM800 presents the lowest value of adsorption capacity, i.e., $337 \mathrm{mg} \mathrm{g}^{-1}$.

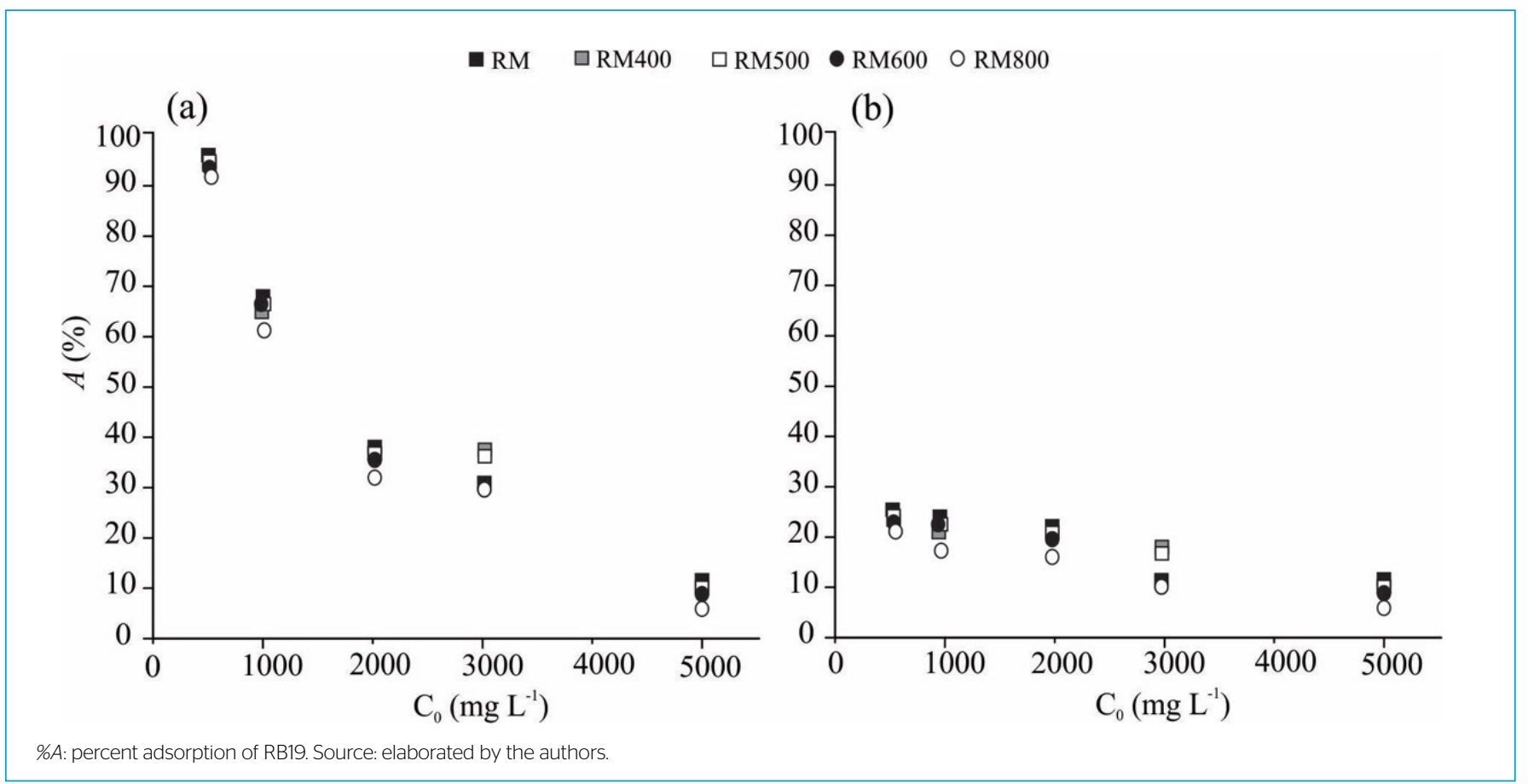

Figure 3 - Dependence of adsorption of RB19 on $\mathrm{C}_{0}$ under different pH conditions: (A) pH 4 and (B) pH10. 
(a)

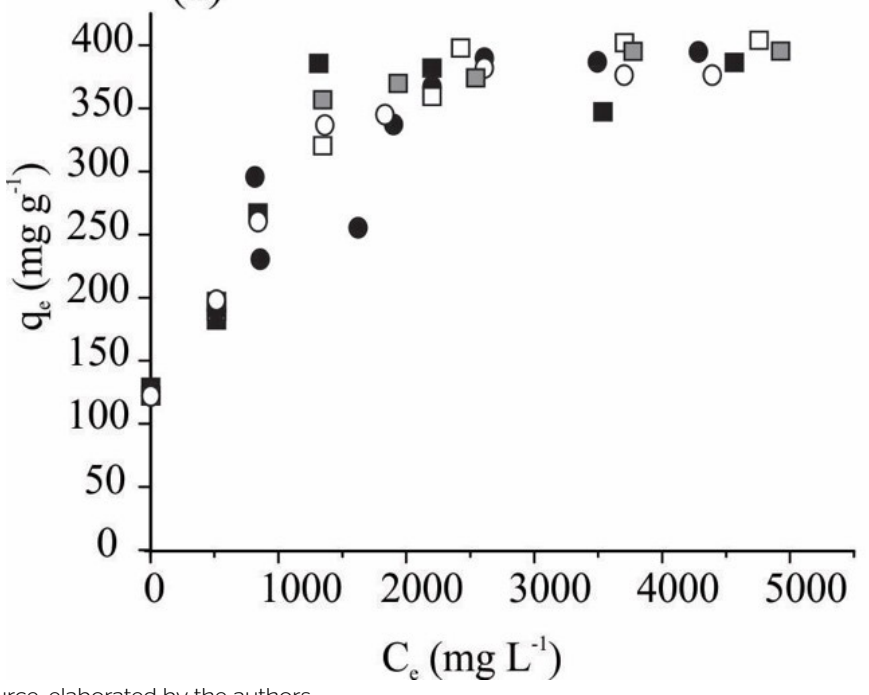

(b)

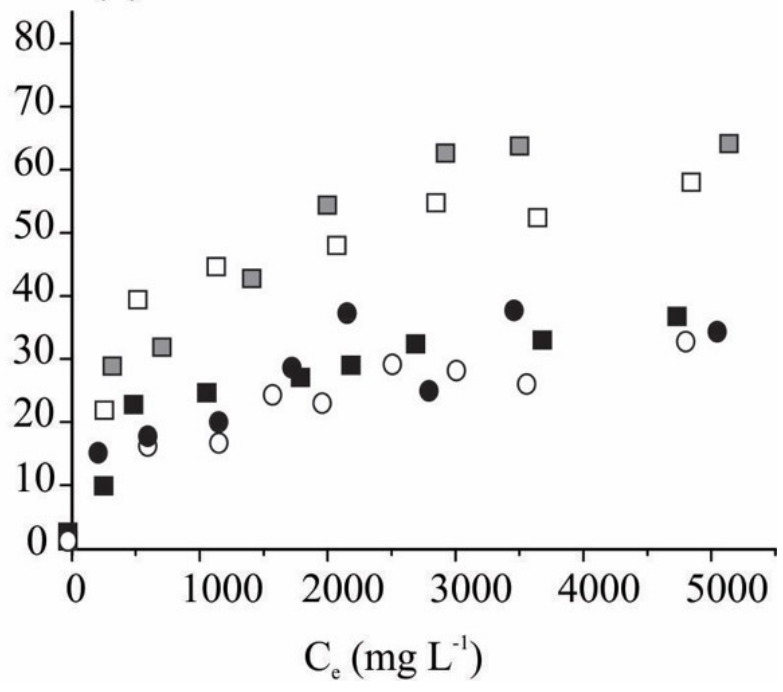

Figure 4 - Relationship between the quantity of RB19 adsorbed onto the different red mud samples $(q)$ versus the equilibrium dye concentration $(C)$. RM, RM400, RM500, RM600, and RM800 at (A) pH 4 and (B) $\mathrm{pH} 10$.

Table 3 - Parameters of adsorption using Langmuir and Freundlich models for the RM, RM400, RM500, RM600, and RM800 at pH 4.0 and pH 10.

\begin{tabular}{|c|c|c|c|c|c|}
\hline Parameter/sample & RM & RM400 & RM500 & RM600 & RM800 \\
\hline \multicolumn{6}{|l|}{$\mathrm{pH} 4$ - Langmuir } \\
\hline$a_{m}\left(\mathrm{mg} \mathrm{g}^{-1}\right)$ & 357 & 403 & 416 & 370 & 337 \\
\hline $\mathrm{K}_{\mathrm{L}}\left(50 \mathrm{~mL} \mathrm{mmol}{ }^{-1}\right)$ & 0.0059 & 0.0051 & 0.0042 & 0.0025 & 0.0064 \\
\hline $\mathrm{R}^{2}$ & 0.95 & 0.89 & 0.95 & 0.97 & 0.94 \\
\hline \multicolumn{6}{|l|}{ pH 4 - Freundlich } \\
\hline $1 / n$ & 4.26 & 4.67 & 4.41 & 3.16 & 4.03 \\
\hline $\mathrm{K}_{\mathrm{F}}\left(\left(\mathrm{mmol} \mathrm{g}^{-1}\right)\left(50 \mathrm{~mL} \mathrm{mmol}^{-1}\right)^{-1 / n}\right)$ & 53.9 & 64.8 & 57.3 & 30.7 & 50.7 \\
\hline $\mathrm{R}^{2}$ & 0.99 & 0.99 & 0.99 & 0.99 & 0.99 \\
\hline \multicolumn{6}{|l|}{ pH 10 - Langmuir } \\
\hline$a_{m}\left(m g . g^{1}\right)$ & 35.8 & 57.7 & 68.7 & 54.1 & 34.9 \\
\hline $\mathrm{K}_{\mathrm{L}}\left(50 \mathrm{~mL} \mathrm{mmol}{ }^{-1}\right)$ & 0.00037 & 0.00014 & 0.0001 & 0.00048 & 0.00042 \\
\hline $\mathrm{R}^{2}$ & 0.64 & 0.34 & 0.22 & 0.61 & 0.78 \\
\hline \multicolumn{6}{|l|}{ pH 10 - Freundlich } \\
\hline $1 / n$ & 1.29 & 1.28 & 1.02 & 1.27 & 1.80 \\
\hline $\mathrm{K}_{\mathrm{F}}\left(\left(\mathrm{mmol} \mathrm{g} \mathrm{g}^{-1}\right)\left(50 \mathrm{~mL} \mathrm{mmol}^{-1}\right)^{-1 / n}\right)$ & 0.11 & 0.09 & 0.03 & 0.07 & 0.13 \\
\hline $\mathrm{R}^{2}$ & 0.99 & 0.99 & 0.99 & 0.99 & 0.99 \\
\hline
\end{tabular}

Source: elaborated by the authors.

Sodalite is a calcium and sodium tectosilicate of open porous structure. It can be considered a material with zeolite-type properties and exhibits permanently negatively-charged surfaces (SMICIKLAS et al., 2014). As the RB19 is a cationic dye, the presence of sodalite can be the main mineral phase related to the adsorption capacity of untreated and thermally treated red mud. Sodalite was abundant in RM, RM400, R500, RM600, and RM800. In addition, there are other minerals that contribute to the adsorption process, i.e.,
$\mathrm{Al}$ and Fe oxides obtained after thermal treatment (SANTONA; CASTALDI; MELIS, 2006)

The influence of the thermal treatment on the $q_{\mathrm{m}}$ values, however, is not associated with the presence of sodalite, since this was found in all samples studied, regardless of the temperature range. Thus, another factor must be responsible for the change in the $q_{\mathrm{m}}$ values during thermal treatment. Figure 5 illustrates the linear relationship between $q_{\mathrm{m}}$ and SSA and clearly indicates that 


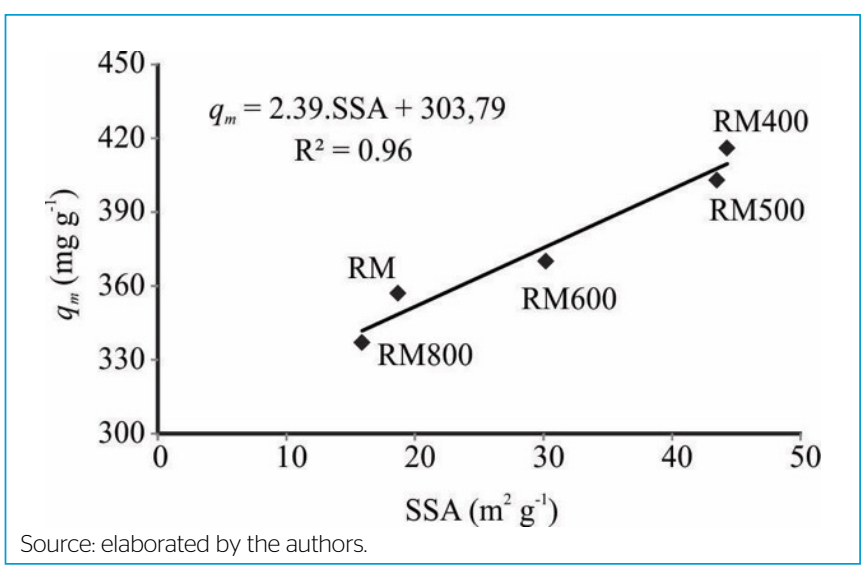

Figure 5 - Relationship between maximum amount of adsorption $\left(q_{\mathrm{m}}\right)$ and SSA.

the variation in SSA values is responsible for the change in the $q_{\mathrm{m}}$ values during the thermal treatment.

\section{CONCLUSIONS}

The thermal treatment does not change the $\mathrm{pH}$ and EC values of the thermallytreated red mud samples. Mineralogical analysis showed that the thermal treatment of the red mud transforms its mineralogy, causing an increase in SSA. The adsorption of RB19 in aqueous solutions on untreated and thermally-treated red mud was highly dependent on the $\mathrm{pH}$ of the solution, with the highest percentage of adsorption occurring at $\mathrm{pH} 4$. The adsorption isotherm model that best represented the adsorption of RB19 into these materials was the Freundlich model. Due to an increase in the specific surface area in relation to untreated red mud $\left(357 \mathrm{mg} \mathrm{g}^{-1}\right)$, the maximum adsorption capacity value $\left(q_{\mathrm{m}}\right)$ was seen at $500^{\circ} \mathrm{C}$ $\left(416 \mathrm{mg} \mathrm{g}^{-1}\right)$. The adsorption of RB19 into untreated and thermally-treated red mud depends on the SSA values. Thus, this study presents an important alternative for the reuse of bauxite refined residue. In addition, red mud processed at $500^{\circ} \mathrm{C}$ can be used for water and wastewater treatment with a greater efficiency than untreated red mud, contributing to the reduction of waste generated, storage costs, and environmental impacts of the process of alumina extraction from bauxite using the Bayer process. Further studies should be conducted, however, to assess whether the energy costs of the thermal treatment are not prohibitive.

\section{AUTHORS' CONTRIBUTIONS}

Antunes, M. L. P.: Conceptualization, Investigation, Writing - Original Draft. Conceição, F. T.: Conceptualization, Writing - Original Draft; Navarro, G. R. B.: Conceptualization, Investigation. Fernandes, A. M.: Conceptualization, Investigation. Durrant, S. F.: Writing - Review \& Editing.

\section{REFERENCES}

ANTUNES, M.L.P.; COUPERTHWAITE, S.J.; CONCEIÇÃO, F.T.; JESUS, C.P.C.; KIYOHARA, P.K.; COELHO, A.C.V.; FROST, R.L. Red Mud from Brazil: thermal behavior and physical properties. Industrial \& Engineering Chemistry Research, v. 51, n. 2, p. 775-779, 2012. https://doi.org/10.1021/ie201700k

BACIOIU, I.G.; STOICA, L.; CONSTANTIN, C; STANESCU, A.M. Removal of Tratazine from aqueous solution by adsorption on activated Red Mud. Water Air Soil Pollution, v. 228, p. 298-307, 2017. https://doi.org/10.1007/s11270-017-3469-3

BHATNAGAR, A.; VILAR, V.J.P.; BOTELHO, C.M.S.; BOAVENTURA, R.A.R. A review of the use of red mud as adsorbent for the removal of toxic pollutants from water and wastewater. Environmental Technology, v. 32, n. 3. p. 231-249, 2011. https://doi.org/10.1080/09593330.2011.560615

BRASIL. Departamento Nacional de Produção Mineral (DNPM). Sumário Mineral. Brasília: DNPM, 2018.

CRINI, G. Non-Conventional low-cost adsorbents for dye removal: a review. Bioresource Technology, v. 97, n. 9, p. 1061-1085, 2006. https://doi. org/10.1016/j.biortech.2005.05.001

FIGUEIREDO, J.L.; SOUSA, J.P.S.; ORGE, C.A.; PEREIRA, M.F.R.; ORFÃO, J.J.M. Adsorption of dyes on carbon xerogels and templated carbons: influence of surface chemistry. Adsorption, v. 17, p. 431-441, 2011. https://doi.org/10.1007/ s10450-010-9272-8

FORTES, G.M.; LOURENÇO, R.R.; MONTINI, M.; GALLO, J.B.; RODRIGUES, J.A. Synthesis and mechanical characterization of iron oxide rich sulfobelite cements prepared using bauxite residue. Materials Research, v. 19, n. 2, p. 276-284, 2016. https://doi.org/10.1590/1980-5373-MR-2015-0180
GOMES, H.I.; MAYES, W.M.; ROGERSON, M.; STEWART, D.I; BURKE, I.T. Alkaline residues and the environment: a review of impacts, management practices and opportunities. Journal of Cleaner Production, v. 112, part 4, p. 3571-3582, 2016. https://doi.org/10.1016/j.jclepro.2015.09.111

GUPTA, V.K.; SUHAS, A.I. Application of low-cost adsorbents for dye removal - a review. Journal of Environmental Management, v. 90, n. 8, p. 2313-2342. 2009. https://doi.org/10.1016/j.jenvman.2008.11.017

GUPTA, V.K.; SUHAS, A.I.; SAINI, V.K. Removal of rodhamine B, fast green, and methylene blue from wastewater using red mud, an aluminum industry waste. Industrial \& Engineering Chemistry Research, v. 43, n. 7. p. 1740-1747, 2004. https://doi.org/10.1021/ie034218g

JESUS, C.P.C.; ANTUNES, M.L.P.; CONCEIÇÃO, F.T.; NAVARRO, G.R.B.; MORRUZI, R.B. Removal of reactive dye from aqueous solution using thermally treated red mud. Desalination and Water Treatment, v. 55, n. 4, p. 1040-1047, 2015.

JONES, B.E.H.; HAYNES, R.J. Bauxite processing residue: a critical review of its formation, properties, storage and revegetation. Critical Reviews in Environmental Science and Technology, v. 41, n. 3, p. 271-315, 2011. https://doi. org/10.1080/10643380902800000

LIAO, C:; ZENG, L.; SHIH, K. Quantitative X-ray Diffraction (QXRD) analysis for revealing thermal transformations of red mud. Chemosphere, v. 131, $p$. 171-177, 2015. https://doi.org/10.1016/j.chemosphere.2015.03.034

LING, S.K.; WANG, S.; PENG, Y. Oxidative degradation of dyes in water using $\mathrm{CO}^{2+} / \mathrm{H}_{2} \mathrm{O}_{2}$ and $\mathrm{Co}^{2+} /$ peroxymonosulfate. Journal of Hazardous Materials, $\mathrm{v}$. 178, n. 1-3, p. 385-389, 2010. https://doi.org/10.1016/j.jhazmat.2010.01.091 
MERCURY, J.M.R.; CABRAL, A.A.; PAIVA, A.E.M.; ANGELICA, R.S.; NEVES, R.F.; SCHELLER, T. Thermal behavior and evolution of the minerals phases of Brazilian red mud. Journal of Thermal Analysis and Calorimetry, v. 104, p. 635-643, 2011. https://doi.org/10.1007/s10973-010-1039-7

MOHAN, N.; BALASUBRAMANIAN, N.; SUBRAMANIAN, V. Electrochemical treatment of simulated textile effluent. Chemical Engineering and Technology, v. 24, n. 7. p. 749-753, 2001. https://doi.org/10.1002/15214125(200107)24:7\%3C749::AID-CEAT749\%3E3.O.CO;2-Y

NAMASIVAYAM, C.; ARASI, D.J.S.E. Removal of congo red from wastewater by adsorption onto waste red mud. Chemosphere, v. 34, n. 2, p. 401-417, 1997. https://doi.org/10.1016/S0045-6535(96)00385-2

NAMASIVAYAM, C.; YAMUNA, R.T.; ARASI, D.J.S.E. Removal of acid violet from wastewater by adsorption on waste red mud. Environmental Geology, v. 41, p. 269-273, 2001. https://doi.org/10.1007/s002540100411

NAMASIVAYAM, C.; YAMUNA, R.T.; ARASI, D.J.S.E. Removal of procion orange from wastewater by adsorption on waste red mud. Separation Science and Technology, v. 37, n. 10, p. 2421-2431, 2002. https://doi.org/10.1081/SS120003521

NOROUZI, S.; BADII, K.; ARDEJANI, F.D. Activated bauxite waste as an adsorbent for removal of Acid Blue 92 from aqueous solutions. Water Science \& Technology, v. 62, n. 11, p. 2491-2500, 2010. https://doi.org/10.2166/ wst.2010.514

OLIVEIRA, E.H.C.; MENDONÇA, E.T.R.; BARAÚNA, O.S.; FERREIRA, J.M.; MOTTA SOBRINHO, M.A. Study of variables for optimization of the dye indosol adsorption process using red mud and clay as adsorbents. Adsorption, v. 22, p. 59-69, 2016. https://doi.org/10.1007/s10450-015-9742-0

PAPIC, S.; KOPRIVANAC, N.; BOZIC, A.L.; METES, A. Removal of some reactive dyes from synthetic wastewater by combined Al(III) coagulation/ carbon adsorption process. Dyes and Pigments, v. 62, n. 3, p. 291-298, 2004. https://doi.org/10.1016/S0143-7208(03)00148-7

POWER, G.; GRÄFE, M.; KLAUBER, C. Bauxite residue issues: I. Current management, disposal and storage practices. Hydrometallurgy, v. 108, n. 1-2, p. 33-45, 2011. https://doi.org/10.1016/j.hydromet.2011.02.006

RATNAMALA, G.M.; SHETTY, K.V.; SRINIKETHAN, G. Removal of remazol brilliant blue dye from dye-contaminated water by adsorption using red mud: equilibrium, kinetic, and thermodynamic studies. Water, Air, \& Soil Pollution, v. 223, p. 6187-6199, 2012. https://doi.org/10.1007/s11270-012-1349-4

SAHU, M.K.; SAHU, U.K.; PATEL, R.K. Adsorption of safranin-O dye on $\mathrm{CO}_{2}$ neutralized activated red mud waste: process modelling, analysis and optimization using statistical design. RSC Advances, v. 5, n. 53, p. 4229442304, 2015. https://doi.org/10.1039/C5RAO3777H
SANTONA, L.; CASTALDI, P:; MELIS, P.Evaluation of theinteractionmechanisms between red mud and heavy metals. Journal of Hazardous Materials, v. 136, n. 2, p. 324-329, 2006. https://doi.org/10.1016/j.jhazmat.2005.12.022

SHIRZAD-SIBONI, M.; JAFARI, S.J.; GIAHI, O.; KIM, I.; LEE, S.M.; YANG, J.K. Removal of acid blue 113 and reactive black 5 dye from aqueous solution by activated red mud. Journal of Industrial and Engineering Chemistry, v. 2O, n. 4, p. 1432-1437, 2014. https://doi.org/10.1016/j.jiec.2013.07.028

SILVA FILHO, E.B.; ALVES, M.C.M.; MOTTA, M.; OLIVEIRA, E.H.C.; BRANDER JUNIOR, W. Estudo sobre a utilização da lama vermelha para a remoção de corantes em efluentes têxteis. Química Nova, v. 31, n. 5, p. 985-989, 2008. https://doi.org/10.1590/S0100-40422008000500008

SMICIKLAS, I.; SMILJANIC, S.; PERIC-GRUJIC, A.; SLJIVIC-IVANOVIC, M. MITRIC, M.; ANTONOVIC, D. Effect of acid treatment on red mud properties with implications on Ni(II) sorption and stability. Chemical Engineering Journal, v. 242, p. 27-35, 2014. https://doi.org/10.1016/j.cej.2013.12.079

SOJKA-LEDAKOWICZ, J.; ZYLLA, R.; MROZINSKA, Z.; PAZDZIOR, K.; KLEPACZSMOLKA, A.; LEDAKOWICZ, S. Application of membrane processes in closing of water cycle in textile dye-house. Desalination, v. 250, n. 2, p. 634 638, 2010. https://doi.org/10.1016/j.desal.2009.09.039

SOUZA, K.C.; ANTUNES, M.L.P.; CONCEIÇÃO, F.T. Adsorção do corante reativo azul 19 em solução aquosa por lama vermelha tratada quimicamente com peróxido de hidrogênio. Química Nova, v. 36, n. 5, p. 651-656, 2013. https:// doi.org/10.1590/S0100-40422013000500007

SOUZA, K.C:; ANTUNES, M.L.P;; COUPERTHWAITE, S.J.; CONCEIÇÃO, F.T; BARROS, T.R.; FROST, R. Adsorption of reactive dye on seawater-neutralised bauxite refinery residue. Journal of Colloid and Interface Science, v. 396, p. 210-214, 2013.

STEPHENSON, R.J.; DUFF, S.J.B. Coagulation and precipitation of mechanical pulping effluent - I. Removal of carbon, colour and turbidity. Water Research, v. 30, n. 4, p. 781-792, 1996. https://doi.org/10.1016/0043-1354(95)00213-8

TOR, A.; CENGELOGLU, Y. Removal of congo red from aqueous solution by adsorption onto acid activated red mud. Journal of Hazardous Materials, v. 138, n. 2, p. 409-415, 2006. https://doi.org/10.1016/j.jhazmat.2006.04.063

WANG, Q.; LUAN, Z.; WEI, N.; LI, J.; LIU, C. The color removal of dye wastewater by magnesium chloride/red mud (MRM) from aqueous solution. Journal of Hazardous Materials, v. 170, n. 2-3, p. 690-698, 2009. https://doi.org/10.1016/j. jhazmat.2009.05.011

WANG, S.; BOYJOO, Y.; CHOUEIB, A.; ZHU, Z.H. Removal of dyes from aqueous solution using fly ash and red mud. Water Research, v. 39, n. 1, p. 129-138, 2005. https://doi.org/10.1016/j.watres.2004.09.011

WEFERS, K.; MISRA, C. Oxides and hydroxides of aluminium. Technical Paper no 19. Pittsburg: ALCOA Research Laboratories Center, 1987. 